\title{
ADDITIONS TO THE RECORDED HYMENOPTEROUS FAUNA OF THE PHILIPPINE ISLANDS, WITH DESCRIPTIONS OF NEW SPECIES.
}

\author{
By Wiclam H. Asmivad, \\ Ixsiatme Curvtor, Dicision of Inerets.
}

In my previous papers on the Ifymenopterous fauma of the l'hilippine lisands. I thend that I werlooked many species recorded from the archipelago. Bulow, therefore. I ure a list of these omisions and follow with drocriptions of two new genern and twenty-eight new spreies renived recently from Fatber Robert Brown. $\$$. I. of the

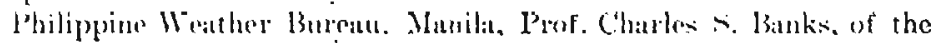
(roverument Labomories. Manila, and Dr. E. A. Marms L. S. A.

\section{Fimily Al'ID.F: \\ TRIGONA BIROI Friese.}

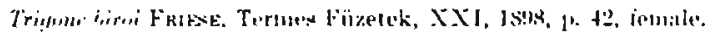

This is the only stingless lunerbere recorded from the istands,

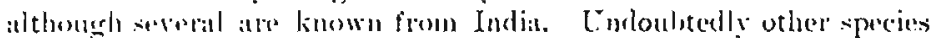
will be fouml.

Family roManIDE:

NOMADA PHILIPPINENSIS Vachal.

NOMIA DIMIDIATA Vachal.“

L:aurily XILOCOPlI).]:

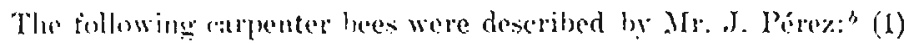

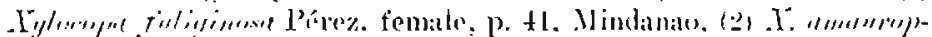

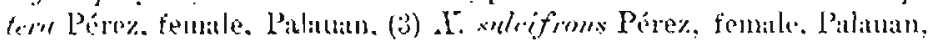

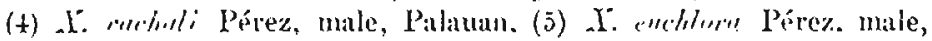

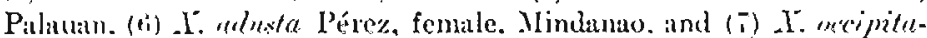
li. Prere. Mind:unio.

1 Miscell. Entom.. V. 1s9\%, p. 8

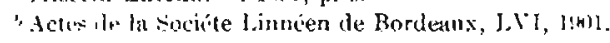

Paoceedings U. S. National Museum, Vol, XXVIII-No. 1413.

Prox. S. Yl vol. sxviii-(1t—bl 


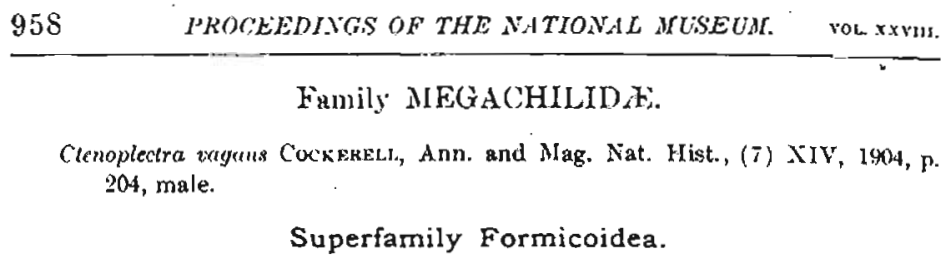

An important paper by Prof. C. Emery, "treating of the ants from the island of Luzon, was overlooked by me. He gives a list of the species and describes some new varieties and species. Here they are:

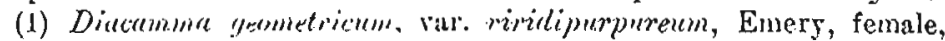

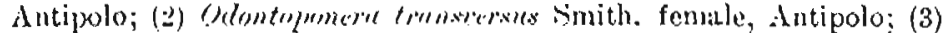

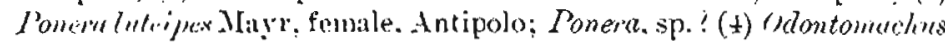
hirmmtadex Limmers, female. Manila; (5) (). infumlus Smith, female, Antipolo: (6) (). prenem. Emery, var. Manila: (i) Bothopmere gla-

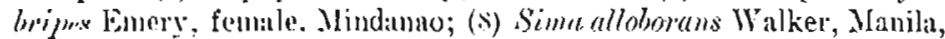

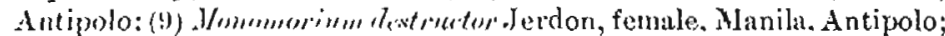

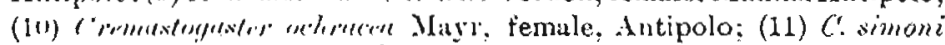
Emery. female. Manila, Antipolo; (12) C. renperi Enery, female, Manilit: (13) C. limgiclare Emery, female, Antipolo; (1t) C. crasciconmis E.mery, female, Manila: (15) C. bicolor Mayr, subsp. imbellis Euners. fomale, Manila; (16) Pheidologeton pyymaens Emery, var. albiprs Emery, female, Antipolo; (1i) Solenopsis geminatu Fabricius, female. Manilit. Antipolo: (1S) Dhtidole simoni Enery, (soldier), Manila: (19) J'. sp., femule, Antipolo; (20) Tetramorium pacificum Mayr. subsp. sulsoulorm Emery, female, Antipolo; (21) Dolichodemus tubernlrtus Mayre, female, Manila, Antipolo, Quruña; (22) Tupinoma melemerephdom Fabricius. female, Manila, Antipolo; (23) Technomyrm, ulbipes sinith, female, Manila; (2t) Ilagiolepis lonyipes Jerdon, female. Antipolo: (25) (Ecophylla smeragrlina Fabricius var. sulmitida Emery, female, Antipolo; (26) Prenlepis, sp., female, Artipolo; (27)

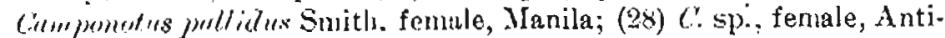

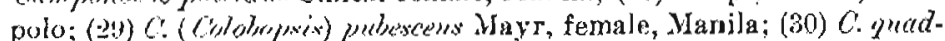
risectux smith. female, Mindanao: (31) C. platypus Roger, female, Mindanaro: (32) C. misuicrms Roger, female, Jolo; (33) C. penneylounieus var. jupmecus Mayr. female, Mindanao; $(3 t) C$ n. sp., female. Mindamo: (35) I'slyrlachis trinac Roger, subsp. saigonensis Forel, female. Nanila, Antipolo: (36) I'. Llowaix subsp. jarana Mayr, fenale, Quruni: (3i) I'. bihamata Drur'y, female, Antipolo: (38) P. pubescens Mayr. femile, Antipolo: (39) $P$. biculor Suith, female, Antipolo: ((1))

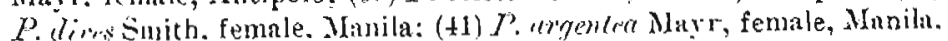
Antipolo.

a Ann. Suc. Eat. France, LXII, 1893, p. 261 et seq. 
DFSCRJPTIONS OF NEW SPECIEX

Fumily BOMBID

Genus BOMBUS Latreille.

I. BOMBUS MEARNSI. new species.

Female-Length $\$ \mathrm{~mm}$. Black, clothed with a long, grayish pubescence, that on the abdomen more or less yellowish, nixed with some bhack huirs, that on the tibice and tarsi ferruginous: ventral segments at apex narrowly testaceons: all tursi and the middle and bind tibie ferruginous; claws black and cleft. The head is smooth and shining, but sparsely and minutely punctured on the face; the mular spuce is distinct, fully as long as wisle: the first joint of the thagellum is about as long as joints 2 and 3 united. while the second joint is only a little longer than thick and nuch shorter than the third. II ings haline, with the stigmal, costal and median reins blackisb, the other veins Haro-testaceous.

Typer-Cat. No. si393, U.S.X.M.

Mindunac. This species is described from a single specinen taken by Dr. E. A. Meurns on Mount A po, at an altitude of b.tk feet. It is the first species to be described from the Pbilippines. and is named in honor of its discoverer:

Fumily PRONOPIDID.K.

Genus PROSOPIS Falincius.

2. PROSOPIS TAGALA, new species.

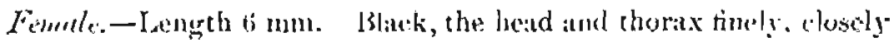
punctite. the trimeralar areat on mitanotum rugrulose. the alklomen smooth and shining: impunctate; the triangulat lateral plates on pach side of the elypeus, a stripe on ench side of the npper margin of the protborax, the protboracic tubercle. a smat! spot on the tegulie anteriorly, and the tibial spurs ace white. rest of hers blacli, but the sutures of the tarsil joints and bencath are more or less ferruginous or brownish. Wings hyaline, the stignia and reins dark lorown, the former being nearly black; the first and second recurrent nervures are, respectively, interstitial with the first and second transierse cubital perrures, the second cabital cell being quadmate. or rery nearly.

Type-Cat. Jo. s:(4), L.S.X.XI.

Manila. Described from a single speeimen receired from Mr. Charles S. Banks, of the Bureau of Gorernment Laboratories. 
Fumily OXYBELID $Æ$.

Genus NOTOGLOSSA Dahlbom.

3. NOTOGLOSSA BANKSI, new species.

Female.-Length, \pm mm. Opanue, hlack, closely, confluently punctured, the face below the antennat and the sternum clothed with sparse, silvery-white hairs; the clypeus his a median ridge and is slightly emarginate anteriorly; the mandibles are testaceous; the prothorucic tubercles, the teguke, $u$ spot on front femora beneath toward apex, the apex of the middle femorn, a broad annulus at the buse of the hind tibia, and all the other thine and tursi are yellowishwhite: the scales on each sicle of the scutellun and the apical Inargins of the emargimte scale at its atpex are also white or yellowish-white; the abdomen is blnck, but then is an oblong white spot on each lateral apical margin of the tirst and sccond segments. Wings hyaline, the stigma and reins brown.

Type-Cat. No. s.201. L.N.X.X.

Manilu. This speries elenely resembles the North American species N. emaryinute s: , but the prothoracic tubercles in that species are not white ancl the enarginated scale at the apex of the scutellum is shorter, mole deeply cmarginate, and quite different in shape.

Only at single specimen is known and was sent me by $\mathrm{Mr}$. Charles S. Banks, in honor of whon the species is named.

\title{
Family I A RRII) \&.
}

\author{
Genus PISON Spinola. \\ 4. PISON PUNCTULATUS, new species.
}

Afrll:-Longth $\rightarrow$ mm. Black and shining, the forehead and the thorax ruely, microscopially punctulate. and clothed with a silvery fubescence. the metathorax striated. the stris on the metanotum oblique, the baxal area not detined, the median sulcus on] slight.jy indicated, with a delicate carina basally; the median sulcus on the trunchture is well defined: legs. including tibial spurs, entirely black: the abdomen is black and impunctate, with a faint silvery pubescence at the sicles and at the apex of the segments, very distinct in certain lights, lut ulsent on the pyidium and the two preceding segments. Wing hyaline, faintly tinted at apex, the stigma and veins black; the second cubital cell is jongry petiolated and neceives the first recurrent nerwe very near its basal angle; the second recurrent nervure is interstitial or neary with the second transverse cubitus.

Type-Cat. No. $\$ 338$, L.S.X.M.

Manila. (Father Rohert Brown.)

Allied to I'. lagune As/mmead, but quitedistinet in punctuation and in metathoracic differences. 


\section{Genus PISONOIDES Smith. \\ 5. PISONOIDES BROWNI, new \$pecies.}

Jfale.- Irength $6 \mathrm{~mm}$. Black and shining. nearly smooth, and clothed with a silvery white pubescence, the elrpeus with a slight triangular process anteriorly, the mesonotum witb two short, grooved lines near the lateral niddle, the metathorax with a crenate-grooved line down the middle and a grooved line on its oblique apical truncature, the truncature being transrersely striated, the netanotum being smontb; the tegule, the subcostal vein, all knees, the front tibia and tarsi, the titial spurs, extreme apex of middle tibite, the apices of the jointy of the waiddle tarsi, and the last joint of the hind tarsi are yellowish; the abdomen is shining, hut distinetly, minutely punctulate, the outer margins and the apices of the segments lwtrally beiner wlothed with a tine. silvery pubescence. Wings byaline, the stigna and reins, except the subcostal rein, black: there are only tue cuhital cells: the second recurrent nervure is nearly interstitial with the tirst transverse unbitus, the first recurrent joins the second cubital cell at its lower hind angle.

Type-Cnt. No. 8332, L.S.X.MI.

Maniln. (Father Robert Brown.)

Pismorides is a good genus and to it helong the Indian specio: placed in I'ison by Colonel J3ingham, under lis section B. nanely: I'. rythro-

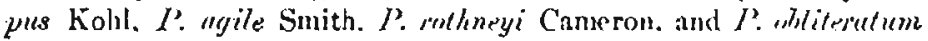
Snith, the last mentioned being the type of the genus.

\section{Fumily 'TRIPOXYLID F.}

Genus TRYPOXYLON Latreille.

6. TRYPOXYLON ELONGATUM, new species.

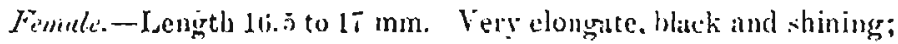
the mandibles. Hagellum boneath, a spot at bise of all tibiac. the extreme buse and apex of the second dowal aldominal segment, the lateral margins of the sime hroadly, and the hase and lateril margins of the third dorsal abdominal segment, are red: the front and middle tarsi and all tibial spur's are rellowish; the head anteriorly, the clypeus (densely), the temples and the sides of the thomx (sparsely) are clothed with a silvery white pubescence: the rerr longly petiolited abdomen is fully twice us long as the head and thorax united, the petiole alone being nearly as long as the thorax. Mings byaline, the stigma and reins black.

Typre-Cat. No. S334, L.S.N.M.

Manila. (Father Robert Brown.) 


\section{Family VESPID无:}

The specific name of the Icaria a recently described by me should read Cagayunensis instead of Cayayanensix. I am indebted to Mr. Charles S. Bauks for culling my attention to this typographical error.

\section{Funily EUMENIDA.}

GenUS LEIONOTUS Saussure.

\section{LEIONOTUS XANTHOZONATUS, new species.}

Fimule.-Length : $\mathrm{mm}$, Binck, the head and thorax coursely punctute, the ibdomen impunctite, but microscopically coriaceously sculptured: the clypeus is corered with a short yollowisb-white pubescence; there is an obligue oblong spot on each side at base of clypeus, at small spot in the incision of the eres. in stripe back of e'es. two nearly conlluent spots on the upper micldle of the pronotum, a spot at base and apex of the tegrula, a spot on the hind angle of the mesonotum next to the tegulie, a spot bencath the tegulie, the post-scutellum, the upical margins of the first and second dorsal segments of the abdomen, "large spot at the apical third of the front and middle femora beneath. and a stripe on the front, middle, and hind tibie outwardly, all yellow; wings smoky hyaline with the stignu and reins black. The tirst joint of the Hagellum is the longest joint, being nearly one-balf longer than the sccond, the following joints to the last gradually shortening, the four joints before the last being a little wider than long.

Type-Cat. Lo. \$335, L.S.X.M.

Manila. (Father Robert Brown.)

\section{Fimily ML'LILLID. $\mathrm{E}$}

Genus Trogaspidia Ashmead.

8. TROGASPIDIA BICOLOR, new species.

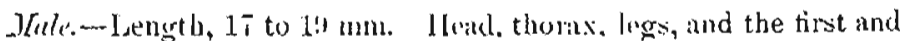
last two seguents of the abdomen black: the rest of the abdomen is red; the head and the thorax are rugovely punctured; the scutellum has a suootb, conically elevation at apex abore: the metanotum bas a broad, smootb, median sulcus. which is broadly widened out at its base; the face, cheeks, legs, and the mesopleuna arc clothed with ather long. somewhat dense, white hairs, almost silvery beneuth the eres; the clypeus is smootl and shining, broadly and stallowly or subsemicimularly emarginute anteriorly; the stape is bicarinate beneath; the wings are hrowa black, with a purplisb tinge, the tegule being large and smooth. with only a farm anattered punctures: the first segment of the abdomen is rather strongry, dosely punctured, bas a large tontl

a Cans. Lint. XXXY, 1(n), p.:3. 
beneath, and is clotbed with long, sparse, whitish hairs; the other segwents a re smooth and shining, although with some sparse punctures, the two apical segments being hlack and clothed with black hairs.

Type-Cat. No. 8202 , U.S.N.M.

Manila. Described from five specimens receired from Mr. Cbarles s. Bunks.

9. TROGASPIDIA MINOR, new species.

Ifale.-Length 12-13 mm. Resembles $T$. biculor very closely, but is considerably smaller and not so closely sculptured on the head: the alklominal segments $L$ to \pm and the base of the fifth are red. the lest black; the median sulcus on the metanoum is not so hroadly dilated at its base as in $T$. bicolor, the wings not so dirk. and with only the faintest tinge of purple in certain lights.

Type-Cat. No. 8203, U.S.N.M.

Manilit. Described front several specimens taken by Mr. ("hatles

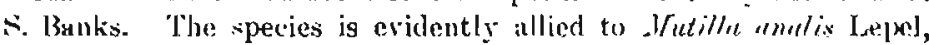
described from India.

Fumily SCELIONII).F.

GenUS MACROTELEIA Westwood.

10. MACROTELEIA MANILENSIS, new species.

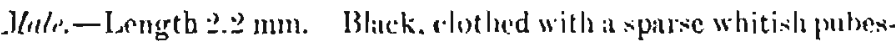
ance. the licad rosely punctured, the thorax more timely punctureyl, the partapsidal furrows indicated by two punetate lines: the supe of

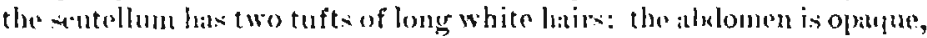
rery ninely sculptured, hat with the extreme als of the segments shining: the leces. in ludine the coxie, are palte brownish yollow. The wings are hyline. but with a faint smoky tinde. the reins heing brownhatk: the marginal rein is only ahout half th" length of the postHaturinal: the stigmal rein is short and delicite. slightly curred, a little shorter than the marginal, and end in a small knob.

rypm-Ciat. No. $\$ 3+1$, U.S.X.M.

Jiunila. (Father liobert Brown.)

Genus SCELIO Latreille.

Ix. SCELIO PHILIPPINENSIS. new species.

3lule-Length - $2.5 \mathrm{~mm}$. Black, the hearl and thomx umbilicately punctate, the mesonotum with parapsidal furrows. but not sharply detined: the scape of the autennat, except at apex. the tegulie. and the legs, except the bind tarsi. which are fuscoun. are irownish yellow. The wings are hraline the apex of the subcostal rein. the small stigma, and the short poststignal and stigmal reins are brown-black. 
The first joint of the funicle is the longest joint; it is obconicnl and about thrice as long as thick at apex, or nearly twice as long as the pedicel; the second, joint is hardly two-thirds the length of the first: the following six joints constitute the club, the joints of which, except the first and the last. which are longer than thick, are not or bardly longer than wide. The abclomen is longitudinally striated, the strive being verr distinct on all the rentmal segments.

Type-Cat. No. B3:36, C.S.N. XI.

Manila. (Futher Rohert Brown.)

\title{
Family PLATM"GASTERIDA.
}

Genus ANOPEDIAS Förster.

12. ANOPEDIAS LUZONICUS, new species.

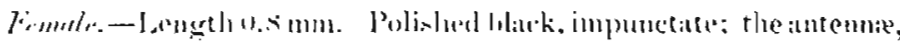

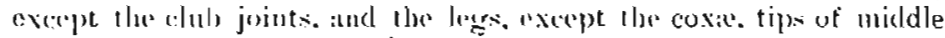
atad hind fenomat, and tips of hind tihiar, are yollow; the joints of the antenmal elub and the coxie are black. while the midlle and bind femorat towatd apex, and the tips of the hind tibie. are brownish.

'The: aldemen is conically pesinted, a litth longer than the hend

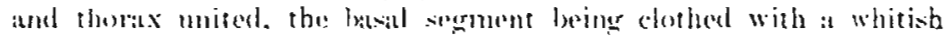
f.thescones.

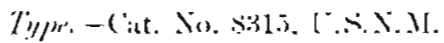

Shanilit: (Fithro Roineret Brown.)

\author{
Fimily ('HAL(II)ID.7:. \\ GenUS CHALCIS LinURUS. \\ 13. CHALCIS BANKSI, new species.
}

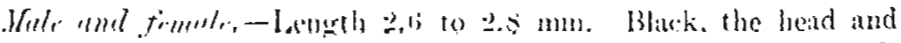

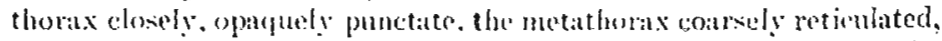

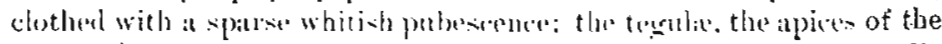

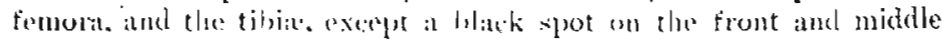

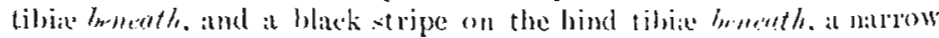
batck ammulas at the lake and at the middle of the himl tibise and all the talsi, except the pulvilli. are white. Wings hyaline the reins hack: the marginal rein is nearly four times as longr ats the stigmal

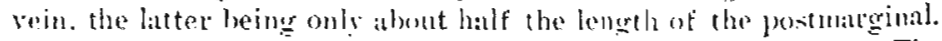
The lews. including the exie. are lighly polished. impuneterte. The abclomen is al so biglyly polished. but dorsal segments $t$ to 7 exhibit some fine punctures toratrd apex.

Type-Cit. Yo. S392. L.S.X.M.

Manila. Describnd from a specimens (Clas. S. Bankst. Allied to C: allowither is Asbmead, hut is quite distinct in the oparguely punctite head and thomx, and in the color of the legrs. 


\section{Family FLRITOMID.̇. \\ Genus EURYTOMA Illiger.}

14. EURYTOMA BANKSI, new species.

Femicle.-Iength $1.6 \mathrm{~mm}$. Stature and general appearance of $E$. monilie, but ditfers decidedly in the color of the antenne and legs. The smpe, except at the extreme apex, the trochnters, more or less. the front tibie, and the middle and hind knees are honey-yellow: the tips of the middle and hind tibie. and all talsi. atre snow-white: the tip of the salpe and the ronded pedicel are hack: the fingellum is brownblack ancl pubescent, the first joint the longest. about twice as long as thick. the following joints (o) the elul shortening. the last heing scarcely longrex than thick.

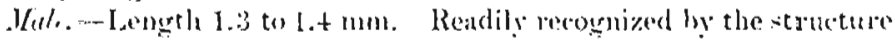
of the intemine. or Hagredlum. and the ablomen. Thi flagellum is a litcle more than thrice ats long as the seape. the funicle joints heing nodose. pedicellate at apex, the nodose part of the joints with whorls of long liatr: the knees of the middle and hind legs are honer-yellow. the front tibia, axeept a brown spot in frout neat the base, the tips of mikklle and hind tibie and all talsi. lesing white. The alylomen is sbort. oral. highly polishod, and istiveded to the thorix by it petioles which is as longer as the? hind coxite.

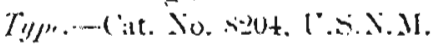

Manilit. (Chamess. Bankis, Many yperimeshs.

15. EURYTOMA ALBOTIBIALIS. new species.

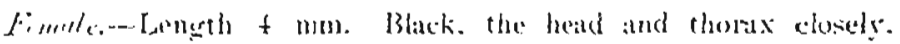
umbilintely punctured, clothed with at hine. sparse. white pubescence;

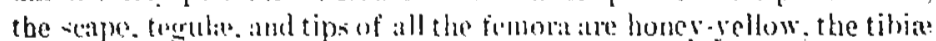
and tarsi white. the tibia toward bast fainty tinged with brown. the rost of the anteunar blatk. The lime joint of the Haerellum is the longrest joint: it is a little more than wrice longer than thich. the following joints to the elub imperceptibly shortening. the club about one-balf longer than the tirst funicle joint. Wings clear hyaline. the reins pale rellowish. the marginal rein being longer than the poutmarginal and thicker: the stigmal rein, with its knoh, is abut balf the length of the marginal. The alselomen is sulypetiolate, con ir-ovatu.

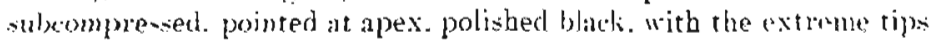
of the sheaths of the oripositor lioner yellor.

Typr.-Citt. So. s.2.j. L.s.s...M.

Manilit. (Cbarles s. Banks.) 


\section{Family EULOPHID E.}

\section{NESOLYNX, new genus.}

This new genus falls into my tribe Elachertini, and in my table of the genera falls between the genera Scotolinx Asbnead and Olynx Forst. The table may be modified to contain it as follows:

11. Mesonotum a little longer than wide.

Abrlomen ovate; fiagellum not.compressed, the joints cylindrical, not or scarcely lonker than thir'k....................... Vesulynux Ashmead. A bdomen conic-ovate; fiagellum compressed, the joints longer than wide.

Olınx Förgter.

\section{NESOLYNX FLAVIPES, new species.}

Female.-Lengtb 0.8 mm. Black and shining, impunctnte, the mesonotum and abclomen with a metallic aeneous tinge in certain lights; scape, pedicel and legs, including the coxe, pale yellowish, the flagellum brown or brown-black; palpi and ternll:e rwate. Wings hyaline, the veins brown; the marginal rein is long. about six times as long as the short stigmal vein, which terminates in a small rounded knob; the prostmarginal vein is long and slender. The ovate uludomen is as long an the hend and thorax united, the basal segment being the longest, the following segments being subequal.

Typr--Cat. No. \$328, L.S.X.M.

Manila. (Father Robert Brown.)

\section{Family ICIINEL:MONID.F.}

Genus CHIODES Förster.

\section{CHIODES OCULATUS, new species.}

Ifale-Length 4.5 mum. Head and thorax black aud shining. impunctate, the metathorax long, arrolated: the eges are very latge and oceupy the whole sides of the hend, conrerging anteriorly, the malar space wbolly wanting: the palpi. trisular. frond cuse sud trodhanters, front tibie and tawi. middle and himl trehanters. more or Jess of the middle tibia and taris. an annulus at bate of hind tibias. the rentral segments 1 to 4 , inclusire. and the basp of dorsal segments 1 and $\supseteq$, are white: base of dorsal ahdominal segments 3 and + yellowish; the rest of the legs, except as hereafter noted, brownish-yellow: the hind coxe have a black spot at hase. the spcond joint of their trochanters, their femora, tibia, and rarsi being fuscous or dark reddish-brown. The antenne, except the first four joints, which are yellom, are black; the first joint of the Hagrllum is a little longer thin the second. The wings are hyaline with the reins, except near the tegula, brown. the costal rein blackish.

Type-Cat. No. 8316 , U.S.X.M.

Manila. (Father Rohert Brown.) One male specinen. 
GenUS MESOSTENUS Gravenhorst.

\section{MESOSTENUS LEUCOZONATUS, new species.}

Mrale-Length $6.5 \mathrm{~mm}$. Black and shiny, impunctate, with the orbits slightly interrupted at apex of eyes, the face below antenna, the clypeus mandibles, except teetli, palpi, an annulus on the antenna, tegulre, a spot beneatl, hind margin of prothorax, a large spot on disk of mesopleura, and the large spot on lower hind end, a line on the hind margin of the same, a large triangle spot at hase of the insertion of the hind sings, the apical half of the metathorax. the apical margins of all the abdominal segnents, the front and middle coxie and trochunters. the apex of the hind coxie. basal two joints of front tarsi and the hind tursi, except base and upex of the first joint. the arpex of joints. two and three and the following joints, whicld are black, pure white, the rest of the legs, except the three terminal joints of front tarsi, apex of middle tibia, their tarsi, apex of hind femora, ale'x of hind tibiar, and all tibial spous, which are bhuck, being red: the antennie; except the first four or five joints beneath and the brokd white anmulus, occupying joints 14 to 16 , are black. Wings hyaline, the stigna and reins black, the arcolate small, nearly quadnte, receiving the second reeurent nervure a little beyond its middle.

Type-Cit. No. S330, C.S.S.MI.

Manila. (Father Lobert Brown.)

NESOMESOCHORINI, new tribe.

NESOMESOCHORUS, new genus. .

This curious new genus is hased upon at singrlo femalds spucimen received recently fron Father Brown, and it position is uncertain. It is romithable in sereral particulas and diblealt to classify. In renation and in the petiolated. compresoct alkhomen it shews some

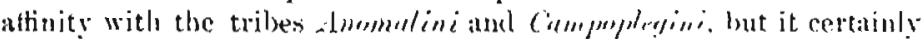
can not belong to ather of these tribes. and in my perplexity ] lave

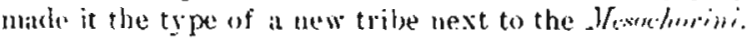

The head is transrerse, the eyes leing abnombally latge and occupsing the whole sides of the head. converging anteriorly and renching to the base of the mandibles, there being no malar space: the clypeus is represented by a small conrex prominence: the mincibles are small and bidentate at apex: the thorax is about two and a half times als loner its thick, narrowed posteriorly. the mesonotum with two shatply detined parapsidal furrows that converge poteriorly: the metathoux is as long as the scutellum, the neso- and pro-notum united, and is distinctly areolated, the basal area being triangular. the areolis being long and hexagonal: the aldomen is about twice at: long as the head and thorax united. strongly compressed and lougly petiolated. and 
ends in a prominent ovipositor. The wing venation is similar to that in Mesochorus, only the stigma is not so well developed but linear, while the areolet is absent, as in some Homitelimi.

19. NESOMESOCHORUS OCULATUS, new species.

Femmle.-Lengrh about is mm.: the wipusitor about one-third the length of the abdomen. Black and shining. impunctate, except the metatborux posteriorly, where the surfu e is wriukled transiersely; the mesopleura bave a kong obliqur. crenate furrow; the antenute are ringed with white, the white ring orecupyeng joints 13 to lit the joints berond, and the 5 or if hefore. being hildk: the other joints. except the pedicel, which is white heing browninh or gellowish: the palpi, the tnumbe, front coxie and trochanters. fhe lirst joint of the midnhe and hind trochatuters. and a narow annulus at hane of hind tillier are

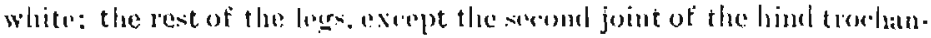

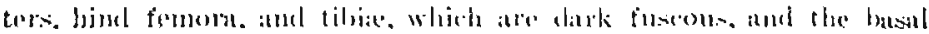
third or more of the atshominal petioles, an remblish-yollow: the second and third dessal segments of the abdenum marnwly at the extreme base. and the venter. are whitish: the first and second alsdominal segmeots are rery long. alumt what in longth: the third and fouth segments suberual. united not lomger than the serond. while the following segmonts are still shorter. Wingr haslime. iridescent. the rovtal and internal benis bown.

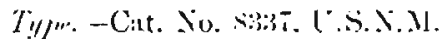

Manila. (Fother Robert Brown.) One spreinmen.

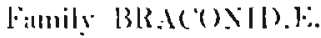

GenUS METEORUS Haliday.

\section{METEORUS BROWNII, new species.}

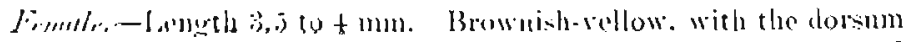
and apex of the metathuris, the apex of the abrominal petiole. and the base of the second dorsal ahdominal nerment hatels: the palpi and tho base of the abdominal petiok ate white: ayes brown or purplist brown in entain lights. The metatherax is regulose. while the abrlomim petiole is longitudiually triated: wings hyaline. iridereent. the costal rein black. the stigma imil internil reius light brownish.

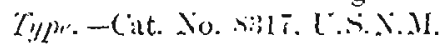

Manila. (Fitber Robert Brown.) Threa specimens. all females.

$$
\text { Genus CHELONUS Jurine. }
$$

\section{CHELONUS ALBICINCTUS. new species.}

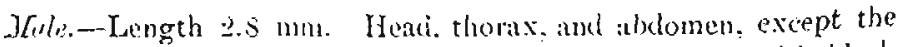
hasal two-tifths. which is whito. black, the mimlinles red with black tecth. the palpi. trocbanters. front tibiat and tatsi, batsal tro-thirls of 
middle tibie, their tarsi, a very brond band on the hind tibie, and the hind tarsi, are white; the front femora are more or less reddish, the middle and hind femora, and the base and apex of the bind tibire, are fuscous black. The wings are hyaline, the internal veins reddishhrown, the stigma piceous. The abdomen is tinely regulose with a cransierse groove or slit at apex.

Type-(at. No. 8318, U.S.N.M.

Nunila. (Father Robert Brown.)

GenUS PHANEROTOMA Wesmael.

22. PHANEROTOMA ALBISCAPA. new species.

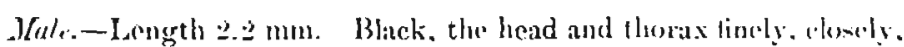
punctate: mandibles gellowish: the palpi. the seapes and pedied of the

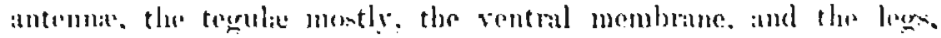

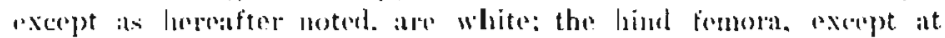

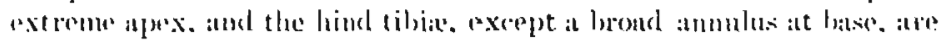
black. The wings ane lyaline. but the appiral two-thirds of the fromt wings hare a fatint smoky tinge: the costal min, the stignit. the hasil rein. and the reins beyond are black or datk brownish-black. while the median and suburedian reins ane. for the most patt. gellowish: the areond abital (roll is lomer triangular and rather marlesw.

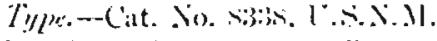

Manila. (lother liobert Brown.)

\section{Genus PSEUDAPANTELES Aslmead. \\ 23. PSF.UDAPANTALES AGILIS, new speci:s.}

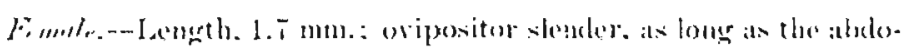
men. liback and shining. the bead and sentellum suooth and shining.

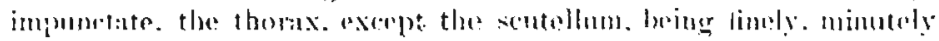

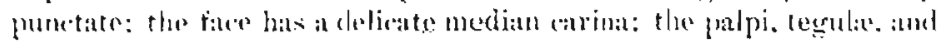

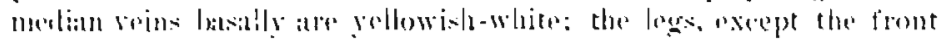

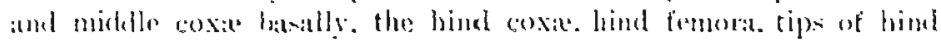
tiliae, and hind tari. which are black or fuscous black, are yellow or light brownish gellow: the abdomen is smooth and shining, the plate

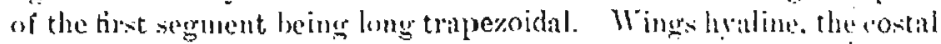
roin. stigma. and post stignal reins heing hrown. the internal veins praler.

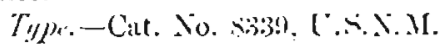

Manila. (Father Robert Brown.) 
Genus BIOSTERES Förster.

24. BIOSTERES LONGICAUDATUS, new species.

Fonale-Length. $3.2 \mathrm{~mm}$; ovipositor longer than the whole insect. Uniformly brownish-yellow, the eyes brown, the antenne very long, gradually becoming black from the basul fourth, the sheaths of the oripositor hlack.

The head and the thorex, except the metantoum, are smooth and impunctate; the parapsidal furrows are deep and converge ancl meet or unite just in front of the scutellum, the latter with a broud deep furrow at basse. which is separated iuto two by a delicate median carina; the metanotum is areolated and punctulute. Wings hyaline, the stigna and reins bown. The alulomen is a little longer than the hemal and thomx united: it is smootb and impunct:ate. 'xeept dorsal segment: 1 and 2 . which are more or less longitudinally striated.

Ty/pe-Cit. So. S3LI\%. U.S.X.M.

Munilia. (Fither loblert Brown.)

Genus RHYSSALUS Haliday.

25. RHYSSALUS UNICOLOR, new species.

Fimmle.-Lengeth 1.5 mm.: ovipusitor shorter than the hind tarsi. brownish yollow. thos sutures of the three-stemented abdomen blackish: strmmaticum blikk: ores purplish brown: antenne toward base (the tirst tive or six joints). the palpi, and the legrs white or yellowish

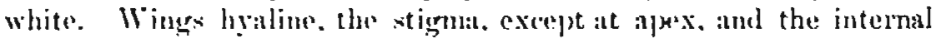
reins, exeept as lereafter uoted, rellowish white: the apex of the stigma, the radius. and the rostul veine brownish. Head and thorax smootl. the metanotum with a forked carina. The alelomen is longitudinally strinted, the serments subopayue.

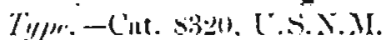

Manili. (Robert Brown.) One sperimen.

Gemus RHOGAS Nees.

26. RHOGAS MELANOSOMA, new species.

Ifill.-Langth $4.5 \mathrm{~mm}$. I Iead and thomax brownish yellow, the ocelli pale and placed on a black spot. the eyes black: the antenne, except the first two joints, a spot at apex of the miclde and hind fenori. more or less of the buse and apex of the hind tibia, the hind tarsi, and the whole dorsum of the abdomen, are liack. The abdomen is rigulose, the first. second, and third segments with a median longitudinal carina, that on the third sulrobsolete. Wings byaline, the stigma and reins brown.

Tyjer-Cirt. No. S3:1, L.S.X.Xl.

Iinila. (Father Brown.) 


\section{Genus BRACON Fabricius.}

27. BRACON YAU, new species.

Female.-Length $2 \mathrm{~mm}$; ovipositor about two-thirds the length of the nbdomen. Black: the renter, a $V$-shaped mark on the second dorsal regment of the ubdomen, and a median line on the following segments are rellow: the scape of the antennie. the mandiblesexcept the teeth, which are bluck, the palpi, the tegulie, and the legs entirely. except the hind tursi, are yellon; the hind tarsi are dark fuscous or blick.

The head and thorax are sumoth and shining impunctute. the partapsidal furow heing indicated by depressed lines that converge posteriorly and nearly met at the bisse of the scuteilum: the clorsum of the abdomen is tinely, opiuguely sentptured or shagreaned.

IIngs hyaline: the stigna and the reins except the median and submolian veins batally, aro dark brown; the recond cubital well is rather narrow. only alsout two-thirils longer than wide al :pex. the second arustrise cubitus being shorter than the tirst.

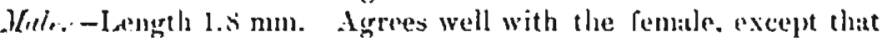
the :ntennie are longer, the leges entirely yellow, the hind tari not fusous, while the median rellow line is nbont on the two lawt segrments.

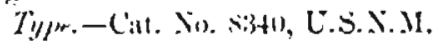

Manila. (Father Rolsert Brown.)

Fimily NEI.ANDRIID.F.

GenUS PARASELANDRIA Ashmead.

28. PARASELANDRIA IMITATRIX. new species.

W.1..-Length $3 \mathrm{~mm}$. Blith and shining. inpunctute. the anterior tibise in front and tbe apex of middle tibiae rellowish: apices of the joints of middle tarsi atre alsu rellowish: the hemal hats two loroul antennal sulci: the third joint of the antenna is the longest. a little longre than the two preceding joints united or a litte longer than the fourth. the following joints shortening. Irings smoky black. the stigma and reins brown black.

Ty/\%.C-Cat. Jo. 33\%2. U.S.N.M.

Manila. (Father lobert Brown.) One specimen.

Tbis is the tirst sartly I have seen from the Philippines. 